\title{
Waste Tyre Management in Gauteng, South Africa: Government, Industry and Community Perceptions
}

\author{
Edison Muzenda and Christina Popa
}

\begin{abstract}
Waste tyres have accumulated at landfills in South Africa, some are illegally dumped in open spaces or sold. This work discusses the waste tyre problem in South Africa as well as the environmental and economic benefits of waste tyre utilization for green fuels. The perceptions of government, industry and community on waste tyre management were investigated. To achieve the objectives a triangulation procedure was followed. This included personnel interviews, questionnaires and literature analysis. The research has shown that lack of knowledge particularly in the informal sector contributed to the waste tyre management problem. The lack of clear and focused legislation guiding the disposal and recycling of waste tyres remains a challenge. Pyrolysis was found to have the potential to address the waste tyre problem with the potential to reduce environmental impact and also contribute towards a green economy.
\end{abstract}

Index Terms-Economic, environmental, green fuel, pyrolysis, triangulation.

\section{INTRODUCTION}

The growing world population, rapid industrialization and vast quantities of solid waste generated daily have contributed to energy crisis and environmental degradation challenges facing mankind today. The scrap tyre is one of the very common and most important hazardous solid waste the world over [1]. Therefore it is important to recover resources from non-conventional sources such as waste tyres and refused plastics. Illegal disposal of waste tyre in communities poses a major environmental and health risk challenge. The discarded tyres accumulate at the landfill sites and due to their durable nature, they are almost immune to biological degradation [2]. As a result, waste tyre land filling has been banned in most countries including South Africa [3]. Open dumping results in breeding sites for mosquitoes and rodents, and give rise to accidental fires with high pollution emissions and health hazards [2]. The use of worn out tyres increase road accidents putting peoples' lives in danger. Alternative waste tyre management processes such as retreading, reclaiming, incineration, grinding exist but have not been able to address the ever growing waste tyre stockpiles at the landfills and illegal dumpsites [4]. Pyrolysis as an alternative to waste tyre land filling has been investigated [2]. It has

Manuscript received May 20, 2014; revised July 15, 2014.

E. Muzenda is with the Department of Chemical Engineering, Faculty of Engineering and the Built Environment, University of Johannesburg, Doornfontein, Johannesburg 2028 (e-mail: emuzenda@uj.ac.za).

C. E. Popa is with the Department of Mechanicall and Industria Engineering Technology, Faculty of Engineering and the Built Environment, University of Johannesburg, Doornfontein, Johannesburg 2028 (e-mail: cpopa@uj.ac.za). received increased attention as the process conditions may be optimized to produce high energy density liquids, char and gases. In addition steel is also recovered from the waste tyres. Pyrolysis involves the thermal decomposition of waste tyres at high temperatures $\left(300-900^{\circ} \mathrm{C}\right.$ in the absence of oxygen. Reference [2] reported that pyrolysis offers an environmentally friendly method for the decomposition of large amount of waste tyres as minimum emission is produced except fugitive sources and equipment leaks. The waste tyre derived oil has been found to have a high calorific value of around $41-44 \mathrm{MJ} / \mathrm{kg}$, making it a suitable substitute for convectional liquid fuels [5]. Carbon black could be used as smokeless fuel [3]. The upgrading of these products could greatly improve the economics of waste tyre pyrolysis.

\section{A. Waste Tyre Management}

Waste tyre management encompasses the collection and transportation, storage and pre- processing for delivery, the funding and operations aimed at reducing waste tyres from the environment [6]. Waste tyres fall under the general waste category. About 1.4 billion tyres are sold worldwide each year [7]. In South Africa, approximately 11 million tyres are currently sold and 275000 tonnes of these tyres become waste.

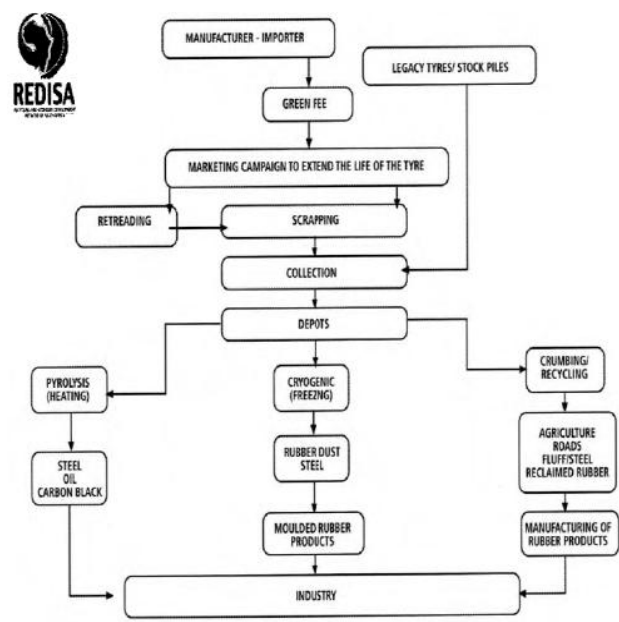

Fig. 1. REDISA waste tyre hierarchy.

\section{B. Waste Tyre Hierarchy}

Old tyres are usually retreaded, reclaimed, devulcanised to rubber for re-use or further processed [8]. In South Africa, the Recycling and Economic Development Initiative of South Africa (REDISA) plan, Fig. 1 is accepted as a comprehensive and inclusive plan with the potential to address the waste tyre problem. The foundation of the waste tyre hierarchy is waste prevention. This could be achieved through recycling and 
re-use of waste tyres with material and energy recovery is the last option [6]. Disposal to landfills is not considered as landfilling is undesirable and does not form part of the long term waste management strategy [9].

\section{Waste Tyre Prevention}

The REDISA plan aims to educate consumers about tyre maintenance and procedures as recommended by tyre producers. This is achieved through country wide awareness campaigns aimed at promoting keeping tyres in good condition and prolonging the lifespan of tyres. Secondly the REDISA plan encourages investors to invest in the tyre retreading industry [6].

\section{Recycling and Re-Use}

Due to their highly complex nature, composition of the raw material and the structure of the rubber from which tyres are manufactured, waste tyres are difficult to recycle [10]. The re-use of waste tyres is defined as "the utilization of waste tyres, in whole or in parts, without changing the composition of the tyre".

\section{E. Recovery}

Waste tyres are also used as an energy source in power plants, tyre manufacturing facilities, cement kilns and as well as pulp and paper production. Waste tyres can also be used as secondary fuel in thermal power plants to reducing coal usage and $\mathrm{NO}_{\mathrm{x}}$ emissions [7]. Waste tyre pyrolysis produces oil, gas and carbon black. The pyrolytic gas has the potential to replace natural gas or propane, providing energy/ heat. The pyrolytic oil has been found to have a high calorific value of around 41-44 $\mathrm{MJ} / \mathrm{kg}$ with the potential to replace convectional liquid fuels [11]. The carbon black can be used as clean solid fuel and in several environmental remediation applications. It can also be gasified for the production of fuel gas and used in various other applications such as batteries, fuel cells and nuclear power plants [12].

\section{F. Sustainability of Waste Tyre Pyrolysis}

The success of any tyre processing technology depends on environmental performance (emissions) and process economics [2]. The continuous supply of waste tyres is required to ensure waste tyre pyrolysis sustainability. Pyrolysis of waste tyres produces a wide range of useful products. The gases can sustain the energy requirements of the pyrolysis plant. Pyrolytic oil may be used directly as liquid fuel or added to petroleum refinery feedstock. Murugan et al (2008) [9] reported the modification of the waste tyre derived pyrolysis oil in three stages namely removal of moisture, desulphurization and vacuum distillation.

\section{G. Economic Profitability}

Waste tyre pyrolysis profitability depends on product price, production capacity, total production cost, capital investment and tipping fee [1]. The low cost of waste tyres can significantly contribute to the profitability of waste tyre pyrolysis. Pyrolysis economics is also influenced by product yield and quality. The REDISA plan is centered on job creation. The attachment of rand value to waste delivered at depots discourages the burning and illegal dumping. This also provide small entrepreneurs and the previously disadvantaged an opportunity to earn an income through the delivery of tyres to collection depots throughout the country. The REDISA plan will also provide the relevant training and create business opportunities ensuring sustainability of waste supply [6]. One of the challenges faced by Small Medium-Micro Enterprises (SMMEs) and Broad-Based Black Economic Empowerment (BBBEE) is access to capital to start businesses. The REDISA plan will fund depots and lease them to BBBEE entrepreneurs. The informal sector will also be involved since a large proportion of the waste tyres (about 75\%) end up in informal settlements and townships [6]. Without the participation of the informal sector the plan will not succeed. A detailed discussion and analysis of the REDISA plan was given [13], [14].

\section{Methodology}

\section{A. Interviews}

1) Waste tyre management companies were interviewed to gather information on the amount of landfilled waste tyres.

2) Government officials were interviewed to gather information on government projects and waste tyre management information. .

3) Operating and non-operating pyrolysis plants personnel helped to gather information on production cost, existing and potential product markets and prices.

\section{B. Questionnaires}

Questionnaires were developed and distributed to evaluate the problems associated with waste tyre management and utilization. Informal sector's perspective on waste tyre management and job creation opportunities helped in gathering waste tyre pyrolysis sustainability information. Questionnaires were distributed to people in townships, rural areas, and informal settlements. Questionnaires were also developed for relevant departmental officials, private agencies, tyre producers and waste tyre pyrolysis plants personnel.

\section{Site Visits}

Landfill sites and waste tyre pyrolysis plants in Gauteng province, South Africa were visited.

\section{RESULTS AND DISCUSSION}

\section{A. Data Analysis: Questionnaires}

Table I shows the distribution pattern for the sampled groups.

TABLE I: PERCENTAGE PARTICIPATION OF VARIOUS GROUPS

\begin{tabular}{cll} 
No. & Sampled groups & Percent \\
\hline 1 & Informal sector & 50 \\
2 & Tyre dealers & 15 \\
3 & Local Government & 35 \\
\hline & Total & 100 \\
\hline \hline
\end{tabular}




\section{B. Waste Tyres as a Community Problem}

The majority of the respondents agreed that waste tyres were a problem in communities, Fig. 2(a). 15\% suggested otherwise, this could be unemployed people who benefit from the burning of waste tyres for steel recovery. Others sell waste tyres as second hand tyres. The local government group (14\%) indicated that waste tyres were not a problem to the communities as they were not exposed to the waste tyre problem due to the nature of their work.

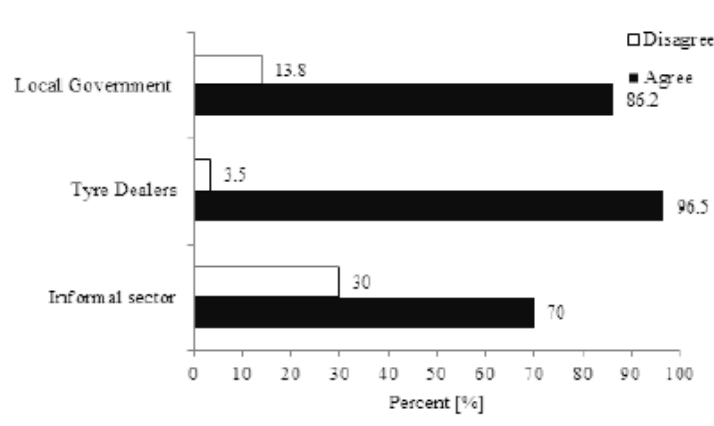

(a)

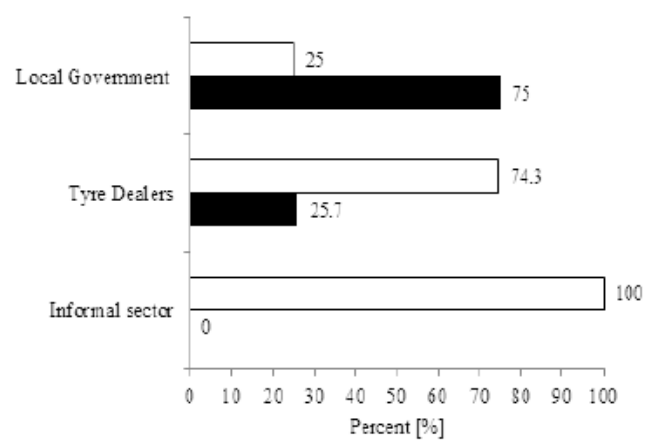

(c)

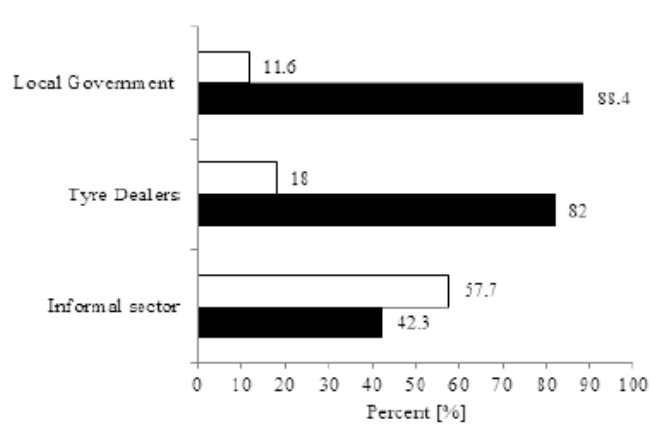

(e)

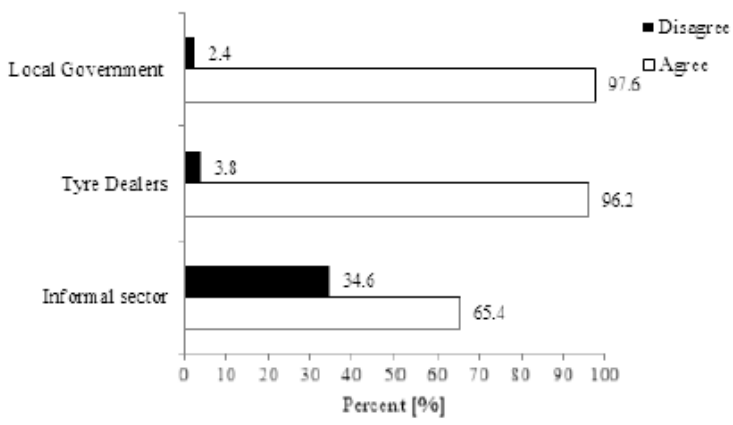

(b)

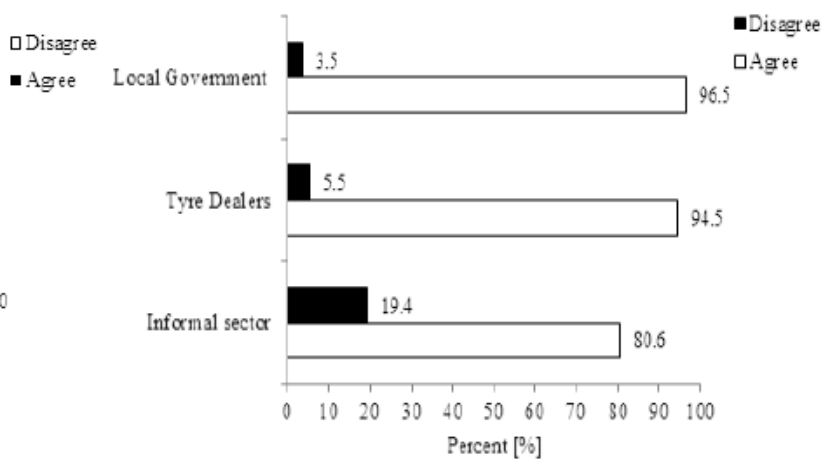

(d)

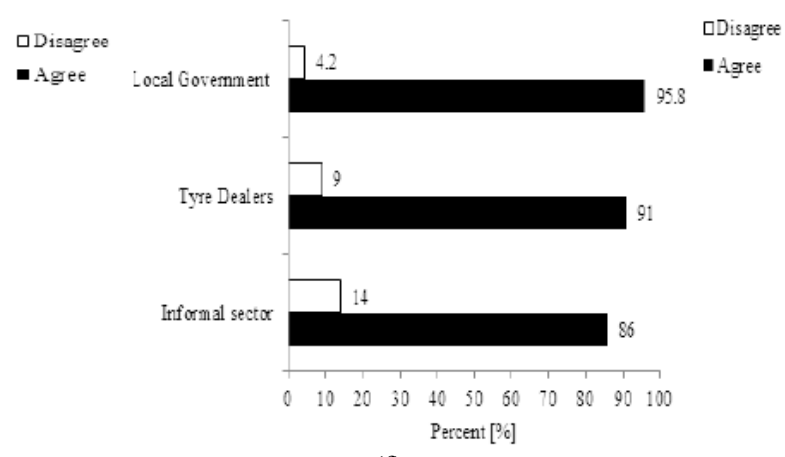

(f)

Fig. 2. Responses (a) waste tyre problem in the community (b) contribution to environmental pollution (c) waste tyre management legal framework (d) pollution reduction through waste tyre utilization (e) Waste tyre utilization (f) job creation opportunities.

\section{Waste Tyre as Contributor to Environmental Pollution}

Waste tyres present fire and health hazards when they are illegally and carelessly disposed of. The burning of tyres releases several noxious gases such as NOx and SOx into the atmosphere. $86.4 \%$ of the participants are aware of the environmental pollution caused by poor waste tyre management. The majority of those who were not aware of the environmental impact were from informal settlements and historically underprivileged communities. The impression of local government was that waste tyres contributed less to environmental pollution compared to the chemical/petrochemical industries.

\section{Legislation Governing Waste Tyre Management}

$66.4 \%$ of the respondents were unaware of any legislation regulating waste tyre management. The response shown in Fig. 2(c) indicated that $75 \%$ of participants from local government, $25.7 \%$ of tyre dealers and none from the informal sector were aware of waste tyre management regulations. The respondents had knowledge of collection, treatment and disposal of waste tyres.

\section{E. Pollution Reduction through Waste Tyre Utilization and Recycling}

$90.5 \%$ of the respondents agreed that waste tyre utilization and recycling may contribute to pollution reduction. Most participants were concerned with the burning of waste tyres as well as illegal dumping. $96.5 \%$ of the local government participants supported pollution reduction through waste tyre utilization and recycling as they are involved in formulating strategies for pollution prevention, waste management and the green economy.

\section{F. Processes or Applications that Utilize Waste Tyres}

Recycling, re-use and recovery is the second step, after 
reduction and prevention, in the waste hierarchy. There are various industrial processes that utilize waste tyres for material and energy recovery. This reduces the volume of landfilled waste. Fig. 2(e) shows that the local government group $(88.4 \%)$ and tyre dealers group ( $82 \%)$ believed that the utilization of waste tyres in applications such as shoe sole making, rubber mats, sports field tracks and road construction is beneficial to the economy. $57.7 \%$ of the informal group considered waste tyres as valuable resources.

\section{G. Employment Creation}

Fig. 2(f) shows that a total of $90.9 \%$ respondents agreed that sustainable green jobs can be created through waste tyre utilization and recycling. Hence government should support such initiatives. One such initiative is the REDISA plan which very inclusive in the whole value chain.

\section{H. Site Visit}

TABLE II: PHYSICAL PROPERTIES OF TYRE DERIVED OIL [15]

\begin{tabular}{|c|c|c|c|}
\hline Property & "Test Method & "Specification & Results \\
\hline Density @20 C $\left(\mathrm{kg} / \mathrm{m}^{3}\right)$ & ASTM D4052 & 0.800 Min & 0.895 \\
\hline Viscosity@40ㄷ (cSt) & ASTM D445 & $2.2-5.3$ & 2.868 \\
\hline Flash Point ( C) & ASTM D93 & $55 \mathrm{Min}$ & $<25$ \\
\hline $\begin{array}{l}\text { Total Contamination } \\
(\mathrm{mg} / \mathrm{kg})\end{array}$ & IP 440 & $24 \operatorname{Max}$ & 31 \\
\hline Total Sulphur (ppm) & ASTM D4294 & Report & 8100 \\
\hline Water Content (vol. \%) & ASTM 6304 & $500 \mathrm{Max}$ & 673 \\
\hline $\begin{array}{l}\text { Distillation }{ }^{\circ} \mathrm{C}: 90 \% \\
\text { Recovery, }{ }^{\circ} \mathrm{C}\end{array}$ & ASTD86 & 362 Max & 378.8 \\
\hline $\begin{array}{l}\text { Micro carbon residue } \\
\text { ( } 10 \% \text { bottoms) }\end{array}$ & ASTM D $\$ 530$ & $0.2 \mathrm{Max}$ & 4.5 \\
\hline Cetane Index & ASTM D4737 & Report & 32.01 \\
\hline
\end{tabular}

TABLE III: PHYSICAL PROPERTIES OF PYROLyTIC CARBON BLACK [15] Description

\begin{tabular}{ccc} 
ON DRY BASIS & & \\
Calorific Value & $\mathrm{MJ} / \mathrm{kg}$ & 31.19 \\
Moisture content & $\%$ & 1.3 \\
Ash content & $\%$ & 14.5 \\
Volatile matter content & $\%$ & 24.3 \\
Fixed Carbon & $\%$ & 59.9 \\
Total Sulphur & $\%$ & 2.61 \\
\hline
\end{tabular}

A pyrolysis plant in Gauteng, South Africa was visited. The plant shred tyres before loading into the reactor. The pieces are heated at $320-350{ }^{\circ} \mathrm{C}$ in the absence of oxygen. The gaseous product was collected in the gas line kept between $320-400^{\circ} \mathrm{C}$. The gas was slowly condensed in three stages using cooling water. The product composition was approximately $40 \%$ oil, $35 \%$ char, $10 \%$ steel and the balance was waste. Waste gas is flared using steam reforming technology before it is released to the atmosphere. The properties of the oil and carbon black from this plant are shown in Table II and Table III respectively.

\section{Economic Evaluation}

An economic analysis was performed on the visited Gauteng Plant based on a 5 year project life. The cash flow figures were calculated based on the following values:

1) Tonnage tyre processing per month 10 ton/day $\times 26$ working days $=260$ tonnes per month.
2) Oil production per month (40\% yield on total tonnage input 10 tonnes per day, 104000.00 litres per month)

3) Steel production per month (10\% yield per total tonnage input 26 tonnes per month)

4) Carbon black production per month (30\% yield on total input 156 tonnes per month)

The total plant cost was R21 500000 (excluding VAT). The cash flow showed a payback period of 3 years. Fig. 3 shows cash flow projections over a 5-year-period. A free cash flow is realized in the 4th year which attracts income tax. Between years 4 and 5 there is a steep increase in cash flow.

Waste tyre pyrolysis was found to be economically feasible when considering a 10 ton/day plant capacity with a payback period of 3 years. The facility created sustainable jobs for about 22 people, producing 104000 litres of tyre derived oil per month at a cost of R4/L, 156 tonnes per month of carbon black at a cost of R 550/ton and 26 tonnes per month of scrap steel at a cost of $\mathrm{R} 700 /$ ton. Continuous supply of waste tyres and product market availability ensure the sustainability of waste tyre pyrolysis.

The approval of the Recycling and Economic Development Initiative of South Africa (REDISA) Integrated Waste Tyre Management Plan by the Minister of Environmental Affairs allows REDISA to address the growing South African waste tyre problem. Waste tyre stockpiles are a fire hazard and a breeding site for mosquitoes and rodents. This Plan has the potential to reduce the environmental impact caused by the burning of waste tyres. It can also create new businesses and green jobs.

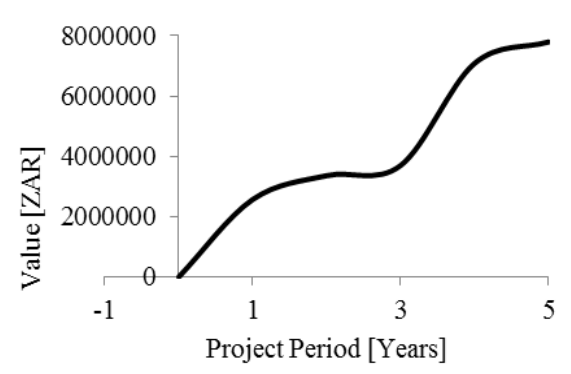

Fig. 3. Cash flow projection for 10 ton/day waste tyre pyrolysis plant [15].

\section{GENERAL DiscusSIONS}

Generally, there is lack of knowledge in the informal sector with regards to environmental management especially on waste tyre disposal and utilization. This reduces entrepreneurship and job creation opportunities. Most participants were not aware of the role of government in waste tyre management. In informal settlements, tyres are burnt for heat generation and also for steel recovery. Pyrolysis is more attractive compared to other thermo-chemical processes such as incineration because of the minimum emissions. Waste tyres have a high calorific value $(35-40 \mathrm{MJ} / \mathrm{kg}$ ) which is greater than most conventional fuels used in power plants. The $\mathrm{CO}_{2}$ emission per unit of energy is much less compared to coal and petroleum. The pyrolysis processes is influenced by temperature, heating rate, residence time, pressure and tyre composition. Tyre derived fuel blends can be used in diesel engines without 
significantly affecting engine performance with an added advantage of reducing emissions in particular smoke, NOx, $\mathrm{CO}$ and $\mathrm{HC}$. Pyrolytic carbon black has a high carbonaceous content $(>80 \mathrm{wt} \%)$.

\section{CONCLUSION}

This work focused on the waste tyre problem in South Africa. The environmental and economic benefits of utilizing waste tyres for green fuels were considered. Although pyrolysis has the potential to address the waste tyre problem, more research is required for the South African environment. Future studies will focus on the feasibility of operating batch pyrolysis plants in South Africa. Studies on stakeholder perceptions should be broadened to cover other interested parties such as non-governmental organizations as well.

\section{ACKNOWLEDGMENT}

The authors acknowledge the University of Johannesburg for financial support.

\section{REFERENCES}

[1] P. T. Williams, Waste Treatment and Disposal, $2^{\text {nd }}$ ed. Wiley \& Sons: London, 2005.

[2] M. A. Wotjowicz and M. A. Serio, "Pyrolysis of scrap tyres: Can it be profitable?" ChemTech, vol. 26, no. 10, pp. 47-52, October 1996.

[3] M. Juma, Z. Korenova, J. Markos, L. Jelemensky, and M. Bafrnec, "Experimental study of pyrolysis and combustion of scrap tyre," Polymer for Advanced Technology, vol. 18, no. 2, pp. 144-148, Feb. 2007.

[4] I. M. Rodriguez, M. F. Laresgoiti, M. A. Cabrero, A. Torres, M. J. Chomon, and B. Caballero, "Pyrolysis of scrap tyres," Fuel Processing Technology, vol. 72, pp. 9-22, August 2001.

[5] A. M. Cunliffe and P. T. Williams, "Composition of oils derived from the batch pyrolysis of tyres," Journal of Analytical and Applied Pyrolysis, vol. 44, no. 2, pp. 131-152, Jan. 1998.

[6] Recycling and Economic Development Initiative of South Africa (REDISA). Government Gazette. (17 April, 2012). [Online]. Available http://www.etyres.co.uk/tyre-construction

[7] J. D. Martinez, N. Puy, R. Murillo, T. Garcia, M. V. Navarro, and A. M Mastral, "Waste tyre pyrolysis : A Review," Renewable and Sustainable Energy Reviews, vol. 23, pp. 179-213, July 2013.

[8] S. Jitkarnka, B. Chusaksri, P. Supaphol, and R. Magaraphan, "Influences of thermal aging on properties and pyrolysis products of tyre tread compound," J. Anal. Appl.Pyrol., vol. 80, pp. 269-276, 2007.

[9] S. Murugan, M. C. Ramaswamy, and G. Nagarayan, "A comparative study on the performance, emissions and combustion studies of DI engine using distilled tyre pyrolysis oil-diesel fuel blends," Fuel, vol. 87, no. 10, pp. 2111-2121, August 2008.

[10] M. Sienkiewicz, J. Kusinska, H. Janik, and A. Balas, "Progress in used tyre management in the Europian Union- A review," Waste Management, vol. 32, no. 10, pp. 1742-1751, 2012.
[11] M. Rofiquel, M. Parveen, H. Hanui, and M. R. I. Sarker, "Innovation in pyrolysis technology for management of scrap Tire: A Solution of Energy and Environment" in Proc. International Journal of Environmental Science and Development, 2010, vol. 1, no. 1, pp. 89-96.

[12] N. Antoniou and A. Zabaniotou, "Features of an efficient and environmental attractive used tyre pyrolysis with energy and material recovery," Renewable and Sustainable Energy Reviews, vol. 20, pp. $539-558,2013$.

[13] N. Nkosi, E. Muzenda, and J. Zvimba, "An Analysis of the Waste Tyre Management Plans in South Africa," in Proc. IIE Int'l Conference Proceedings of International Conference on Innovation in Engineering and Technology, Bangkok, Thailand, 2013, pp. 108-114.

[14] N. P. Nkosi, "Waste tyre management trends and batch pyrolysis studies in Gauteng, South Africa," Masters Dissertation, University of Johannesburg, April 2014.

[15] R Rich, Executive Summary and Business Plan, Milvinetix Pty (ltd), Rosslyn, Pretoria, 2012.

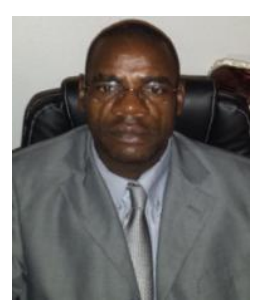

Edison Muzenda is a full professor of chemical engineering, the research and postgraduate coordinator as well as the head of the Environmental and Process Systems Engineering Research Group in the Department of Chemical Engineering at the University of Johannesburg. Professor Muzenda holds a BSc Hons degree in 1994 and a PhD degree in chemical engineering in Birmingham in 2000. $\mathrm{He}$ has more than 15 years' experience in academia which he gained at different Institutions. Through his academic preparation and career, Edison has held several management and leadership positions. Edison's teaching interests and experience are in unit operations, multi-stage separation processes, environmental engineering, chemical engineering thermodynamics, entrepreneurship skills, professional engineering skills, research methodology as well as process economics, management and optimization. He is a recipient of several awards and scholarships for academic excellence. His research interests are in green energy engineering, integrated waste management, volatile organic compounds abatement and as well as phase equilibrium measurement and computation. He has published more than 180 international peer reviewed and refereed scientific articles in journals, conferences and books. Edison has supervised 28 postgraduate students, 4 postdoctoral fellows as well as more than 140 honours and BTech research students.

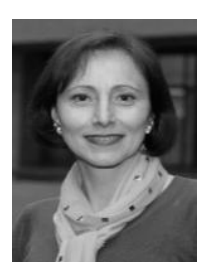

Christina Elena Popa obtained an MTech degree in mechanical from University of Johannesburg in 2013, a BEng degree in mechanical from University of Southern Queensland, Australia in 2006, and a BSc degree in mechanical majoring in chemical and petrochemical equipment in University of Ploiesti, Romania in 1993. She is a lecturer in the Mechanical and Industrial Engineering Technology Department, University of Johannesburg since 2006. Previously she worked as a mechanical engineer for Monticor S.R.L. (Romania) for two years and INDCOOP S.A. (Romania) for four years in various positions. She is a member of ECSA (Engineering Council of South Africa) since 2007. Her interests are in computational mechanics and new welding technologies. 